\title{
Knowledge of breast cancer and practice of self-breast examination among female undergraduates in Uyo, Akwa Ibom State, Nigeria
}

\author{
Olugbemi O. Motilewa*, Uwemedimbuk S. Ekanem, Chukwuemeka A. Ihesie
}

\begin{abstract}
Department of Community Health, Faculty of Clinical Sciences, College of Health Sciences, University of Uyo, Uyo Akwa Ibom, Nigeria
\end{abstract}

Received: 10 October 2015

Revised: 18 October 2015

Accepted: 20 October 2015

\author{
*Correspondence: \\ Dr. Olugbemi O. Motilewa, \\ E-mail: seyimotilewa@yahoo.com
}

Copyright: () the author(s), publisher and licensee Medip Academy. This is an open-access article distributed under the terms of the Creative Commons Attribution Non-Commercial License, which permits unrestricted non-commercial use, distribution, and reproduction in any medium, provided the original work is properly cited.

\begin{abstract}
Background: Breast cancer is the most common cancer globally, and in Nigeria the incidence of the disease has increased over the last two decades. Breast self-examination (BSE) is still the most important way of detecting the disease. Therefore, the study aimed at determining the level of knowledge and attitude of breast cancer and practice of BSE among female undergraduate students.

Methods: This was a cross sectional study of 401 female students that were selected by cluster sampling technique, data was collected using self-administered questionnaires and analysis done using Stata Version 10.

Results: The level of awareness of breast cancer and BSE was high among the respondents, 99\% and $91.3 \%$ respectively; but the knowledge of risk factors for breast cancer was poor. Breast lump was a well-known symptom of breast cancer. Just $20 \%$ of the respondents knew the correct time BSE should be done, and $4 \%$ had a good knowledge of BSE, the practice of BSE was poor, only $9 \%$ of them carried it out monthly; majority of the respondents (88\%) said they will seek help immediately if they observed breast lump, and $80 \%$ were willing to know more about breast cancer. Seven percent of the respondents had previous history of lumps and $6 \%$ had first or second degree relation with breast cancer.

Conclusions: There is a need for appropriate educational programme in order to improve knowledge of breast cancer and practice of BSE among the students for early detection and control of the disease.
\end{abstract}

Keywords: Breast cancer, Breast self-examination, Undergraduate, Uyo

\section{INTRODUCTION}

Breast cancer is the most common cancer in women globally and has become an issue of public health importance. According to the International Agency for Research on Cancer (IARC) GLOBOCAN 2012, 1.7 million women were diagnosed with breast cancer in 2012. ${ }^{1} \quad$ It was responsible for approximately half a million deaths in women worldwide in 2012, affecting both developed and developing countries. This represented a marked increase of $20 \%$ in incidence and $14 \%$ in mortality compared to 2008 estimates. $^{1,2}$
Although the incidence rates vary from less than 40 per 100,000 in most developing regions like Africa and Asia to greater than 80 per 100,000 in developed climes like western Europe and North America, there has been a recent disturbing trend of rising breast cancer incidence in African countries. ${ }^{2,3}$ In Nigeria, a recent review of cancer registries reported a $100 \%$ increase in the incidence of breast cancer in women within the last decade, rising from 24.7 per 100,000 in 1998-1999 to 54.3 per 100,000 in 2009 to $2010 .^{4}$ The rising incidence and mortality from breast cancer in developing countries is a cause of concern to governments and policy makers. 
The rising trend has been linked to factors surrounding lifestyle changes like high fat diet, lack of early detection programmes resulting in a high proportion of late-stage disease presentation and lack of adequate diagnosis and treatment facilities. ${ }^{2}$ In addition, studies have shown that poor knowledge and care-seeking attitude of women for breast cancer contributes significantly to late-stage presentation of breast cancer patients in developing countries. $^{5,6}$

Early detection of breast cancer plays an important role in decreasing its morbidity and mortality. This is especially important in young women in whom the disease is associated with significantly higher mortality. ${ }^{7,8}$ A review of Young university females in 23 countries demonstrated a poor knowledge of risk factors for breast cancer compared to older women. ${ }^{9}$ This necessitates the need for the study focus on young females (15-35 years), as this age group is both at the greatest risk of mortality from aggressive breast disease and has the greatest chance of benefit from early detection interventions like breast self- examination.

This study aims to articulate the level of knowledge and attitude of female undergraduates to breast cancer and assess their practice of breast self -examination. It is hoped that findings from the study can provide vital information for policy direction on breast cancer prevention programs in the University, Akwa Ibom State and Nigeria.

\section{METHODS}

University of Uyo was founded 1991. Until recently it was the only university in the oil rich Akwa Ibom State in the south-south part of Nigeria. The university has two campuses; town campus which has an annex housed the majority of the students, and the permanent campus. All the student hostels are located on the town campus.

A cross sectional descriptive study was carried out among the female undergraduate students of university of Uyo living in the hostel on the town campus. The sample size (n) was determined using $\mathrm{n}=\mathrm{Z}^{2} \mathrm{pq} / \mathrm{d}^{2}$. With a proportion (p) of $50 \%$ and margin of error (d) of $5 \%$ at $1.96 \mathrm{Z}$ score, a value of 384 was obtained. Adding an estimated nonresponse rate of $10 \%$, the sample size was increased to 430 .

\section{Sampling technique}

Cluster sampling technique was used, using the room as a sampling unit. The university has four female hostels (one located at the main campus and 3 at the annex) each of the hostels in the annex has 14 single rooms with 8 students in each room and 13 double rooms with 16 students in each room, while the only hostel in the main campus had 60 rooms and 6 students in each room, the rooms were selected using systematic random sampling technique in each hostel with a sampling interval of 3 .
Data was collected from all the females in the selected rooms who consented to participate in the study, using self- administered structured questionnaire, the first part of the questionnaire was to elicit socio demographic characteristics of the respondents, the second part was on breast cancer knowledge including risk factors and symptoms, the third part was on breast self-examination (BSE), that is knowledge and practice, and the last part was an assessment of risk of the respondents

Data was cleared entered and analysed using STATA version 10, frequencies were expressed in percentages, chi square was used to test for association between two variables and P-value of 0.05 was termed significant. The level of knowledge of breast cancer was categorized into poor $(0-40 \%)$, fair (41-70\%) and good (above $70 \%)$ and the level of knowledge of BSE was categorized into poor (below 50\%) and good (50\% and above).

\section{RESULTS}

A total of 442 questionnaires were administered and 401 $(90.7 \%)$ were cleared entered and analysed. The age range of the respondents is from 16 to 40 , the mean age is $21.3 \pm 2.7$.

Table 1 shows that about $67 \%$ (267) of the respondents were within the age range 21 to 25 years, only $1 \%$ (4) was above 30 years. Majority of them were single (95\%). Students in their $4^{\text {th }}$ year of study constituted about $25 \%$ of the respondents.

Table 2 shows that $99 \%$ of the respondents were aware of breast cancer and $91.3 \%$ were aware of breast selfexamination (BSE). Fig. 1 shows that health workers were the most important source of information on BSE (28.1\%) followed by media (Radio/TV) $22 \%$ while $5.8 \%$ of them got their information from the family members. Table 3 shows that the proportion of the respondents that had correct knowledge of each item of risk factors of breast cancer was low except for smoking (57.6\%), alcohol $(52.1 \%)$ and previous history of breast cancer (54.9); only $46.4 \%$ recognized family history of breast cancer as a risk factor. Breast lump is the most familiar symptoms of breast cancer $(92.5 \%)$ but skin change was not quite known as symptom. Age and the year of study of the respondents had a significant association with the level of knowledge of breast cancer ( $p$ value of 0.026 and 0.031 respectively) as seen in Table 1 . The median knowledge score of breast cancer among the respondents was $42.8 \%$ and $28.9 \%$ had a good knowledge of breast cancer and $46.4 \%$ had poor knowledge.

Table 4 shows that only $20 \%$ knew the correct time to do a BSE and only $2.5 \%$ (10) were able to mention the three correct steps involved in carrying out BSE (look, feel and express nipple for discharge). Only $4 \%$ of the respondents had good overall knowledge of BSE. About $64 \%$ (256) said they practiced BSE but only 9\% (36) carried it out monthly, while about $44 \%$ of the 
respondents had not done BSE in the past three months. About $16 \%$ of the 145 who never did BSE said they did not know how it is done and $38.6 \%$ could not give any reason for not performing BSE, $24 \%$ were not aware of BSE (Figure 2).

Table 1: Socio demographic characteristics and the level of knowledge of breast cancer among the respondents, August 2013.

\begin{tabular}{|c|c|c|c|c|c|}
\hline \multirow{2}{*}{ Characteristics } & \multicolumn{3}{|c|}{ Level of knowledge of breast cancer $n(\%)$} & \multirow{2}{*}{$\begin{array}{l}\text { Total } \\
(n=401)\end{array}$} & \multirow{2}{*}{ Statistical indices } \\
\hline & Poor $(n=186)$ & Fair $(n=99)$ & Good $(n=116)$ & & \\
\hline \multicolumn{6}{|l|}{ Age group } \\
\hline $16-20$ & $43(23.1)$ & $34(34.3)$ & $24(20.7)$ & $101(25.2)$ & \multirow{4}{*}{$\begin{array}{l}\chi^{2}=15.3607 \\
\text { Df }=6 \\
P \text { value } 0.026^{*}+\end{array}$} \\
\hline $21-25$ & $120(64.5)$ & $60(60.6)$ & $87(75.0)$ & $267(66.6)$ & \\
\hline $26-30$ & $19(10.2)$ & $5 \quad(5.1)$ & $5(4.3)$ & $29(7.2)$ & \\
\hline 31 and above & $4(2.2)$ & $0 \quad(0.0)$ & $0 \quad(0.0)$ & $4(1.0)$ & \\
\hline \multicolumn{6}{|l|}{ Year of study } \\
\hline 1 & $23(12.4)$ & $28(28.3)$ & $25(21.6)$ & $76(19.0)$ & \multirow{5}{*}{$\begin{array}{l}\chi^{2}=16.9536 \\
\text { Df }=8 \\
P \text { value }=0.031+*\end{array}$} \\
\hline 2 & $41(22.0)$ & $28(28.3)$ & $27(23.3)$ & $96(23.9)$ & \\
\hline 3 & $46(24.7)$ & $19(19.2)$ & $25(21.6)$ & $90(22.4)$ & \\
\hline 4 & $54(29.0)$ & $18(18.2)$ & $30(25.9)$ & $102(25.4)$ & \\
\hline 5 & $22(11.8)$ & $6(6.1)$ & $9(7.8)$ & $37(9.2)$ & \\
\hline \multicolumn{4}{|l|}{ Marital status } & & \multirow{3}{*}{$\begin{array}{c}\chi^{2}=3.5659 \\
\text { Df }=2 \\
P \text { value }=0.152 *\end{array}$} \\
\hline Single & $174(93.6)$ & $94(95.0)$ & $114(98.3)$ & $382(95.3)$ & \\
\hline Married & $12(6.5)$ & $5 \quad(5.1)$ & $2(1.7)$ & $19(4.7)$ & \\
\hline \multicolumn{6}{|l|}{ Tribe } \\
\hline Ibibio/Annang & $132(71.0)$ & $64(64.7)$ & 75 (64.7) & $271(67.6)$ & \multirow{4}{*}{$\begin{array}{l}\chi^{2}=15.3607 \\
\mathrm{df}=6 \\
\mathrm{p} \text { value }=0.145^{*}\end{array}$} \\
\hline Yoruba & 3 (1.6) & $4 \quad(4.0)$ & $9(7.8)$ & $16(4.0)$ & \\
\hline Igbo & $20(10.8)$ & $15(15.2)$ & $10(8.6)$ & $45(11.2)$ & \\
\hline Others & $31(16.7)$ & $16(16.2)$ & $22(19.0)$ & $69(17.2)$ & \\
\hline
\end{tabular}

Most (88\%) of the respondents said they would seek help immediately, if they observed any breast lump, and $90 \%$ of the respondents said they would consult a doctor for help. About $80 \%$ of the respondents said they were ready to know more about BSE (Table 5).

Table 2: Awareness of breast cancer and Breast selfexamination among the respondents.

\begin{tabular}{|lcc|}
\hline Variables & Frequency & Percentage \\
\hline $\begin{array}{l}\text { Awareness of } \\
\text { breast cancer } \\
\text { Yes }\end{array}$ & 397 & 99.0 \\
\hline $\begin{array}{l}\text { Awareness of } \\
\text { BSE } \\
\text { Yes }\end{array}$ & 366 & 91.3 \\
\hline
\end{tabular}

Table 6 shows that $25 \%$ of the respondents had their menarche before age 13 , the median age of menarche is 13 (IQR 10-16). About 7\% of them had previous history of lump and about $6 \%$ have a first or second degree relation who had breast cancer. While $3.5 \%$ were termed as a high risk because they had family history of breast cancer and at least one of the other risk factors.
Table 3: Correct knowledge of risk factors and symptoms of breast cancer among respondents.

\begin{tabular}{|c|c|c|}
\hline Variables & Frequency & Percentage \\
\hline Risk factors & & \\
\hline Obesity & 159 & 31.7 \\
\hline Women with no child & 97 & 24.2 \\
\hline Smoking & 231 & 57.6 \\
\hline High fat diet & 189 & 47.1 \\
\hline Alcohol consumption & 209 & 52.1 \\
\hline Use of oestrogen pills & 182 & 45.4 \\
\hline No breastfeeding & 85 & 21.2 \\
\hline Early menarche & 80 & 20.0 \\
\hline $\begin{array}{l}\text { Family history of breast } \\
\text { cancer }\end{array}$ & 186 & 46.4 \\
\hline $\begin{array}{l}\text { Previous history of breast } \\
\text { cancer }\end{array}$ & 220 & 54.9 \\
\hline Symptoms of breast cancer & & \\
\hline Breast lump & 371 & 92.5 \\
\hline Breast pain & 259 & 64.6 \\
\hline Skin changes/ ulcer & 163 & 40.7 \\
\hline Bloody discharge & 200 & 49.9 \\
\hline
\end{tabular}




\section{DISCUSSION}

Early detection of breast cancer remains one of the key strategies for the control of breast cancer In Middle and low income countries especially in sub-sahara Africa mammography machines are not available and even where they are, the cost of mammographic screening is not affordable by majority. Thus the knowledge of breast cancer and the practice of BSE will remain key component of early detection in such settings. This is more so among younger women were the disease is known to be more aggressive with accompanying worse outcome. $^{10}$

Table 4: Level of knowledge and practice of BSE among the respondents, August 2013.

\begin{tabular}{|c|c|c|}
\hline Variables & Frequency & Percentage \\
\hline $\begin{array}{l}\text { The correct time for BSE } \\
\text { Before menstruation } \\
\text { Immediately after } \\
\text { menstruation } \\
\text { Any time } \\
\text { Don't know }\end{array}$ & $\begin{array}{l}37 \\
82 \\
142 \\
140\end{array}$ & $\begin{array}{l}9.2 \\
20.4 \\
35.4 \\
34.9\end{array}$ \\
\hline $\begin{array}{l}\text { List three steps you will do } \\
\text { in BSE } \\
\text { Mentioned One correct } \\
\text { Mentioned Two correct } \\
\text { Mentioned Three correct } \\
\text { Don't know }\end{array}$ & $\begin{array}{l}78 \\
51 \\
10 \\
262\end{array}$ & $\begin{array}{l}19.5 \\
12.7 \\
2.5 \\
65.3\end{array}$ \\
\hline $\begin{array}{l}\text { Overall level of knowledge } \\
\text { of BSE } \\
\text { Good } \\
\text { Poor } \\
\text { Not aware of BSE }\end{array}$ & $\begin{array}{l}16 \\
350 \\
35\end{array}$ & $\begin{array}{l}4.0 \\
87.3 \\
8.7\end{array}$ \\
\hline $\begin{array}{l}\text { Do you practice BSE } \\
\text { Yes } \\
\text { No } \\
\text { Not aware of BSE }\end{array}$ & $\begin{array}{l}256 \\
110 \\
35\end{array}$ & $\begin{array}{l}63.8 \\
27.4 \\
8.7\end{array}$ \\
\hline $\begin{array}{l}\text { How often do you perform } \\
\text { BSE } \\
\text { Weekly } \\
\text { Monthly } \\
\text { Three monthly } \\
\text { Yearly } \\
\text { Not regular } \\
\text { Do not practice BSE }\end{array}$ & $\begin{array}{l}55 \\
36 \\
9 \\
8 \\
148 \\
145\end{array}$ & $\begin{array}{l}13.7 \\
9.0 \\
2.2 \\
2.0 \\
36.9 \\
36.2\end{array}$ \\
\hline $\begin{array}{l}\text { Last time you did BSE } \\
\text { Within the last } 2 \text { weeks } \\
\text { About a month ago } \\
\text { In the past three months } \\
\text { In the past } 6 \text { months } \\
\text { More than } 6 \text { months ago } \\
\text { Do not practice BSE }\end{array}$ & $\begin{array}{l}114 \\
111 \\
12 \\
2 \\
17 \\
145\end{array}$ & $\begin{array}{l}28.4 \\
27.7 \\
3.0 \\
0.5 \\
4.2 \\
36.2\end{array}$ \\
\hline
\end{tabular}

The awareness on breast cancer was very high among the respondents $99 \%$, this is more than $87.8 \%$ and $85.7 \%$ reported among rural women in Ife and Ibadan respectively. ${ }^{11,12}$ The knowledge of the risk factors among the respondents was very low, except for smoking, alcohol consumption and previous history of breast cancer. Only $47 \%$ recognized family history of breast cancer as a risk factor.

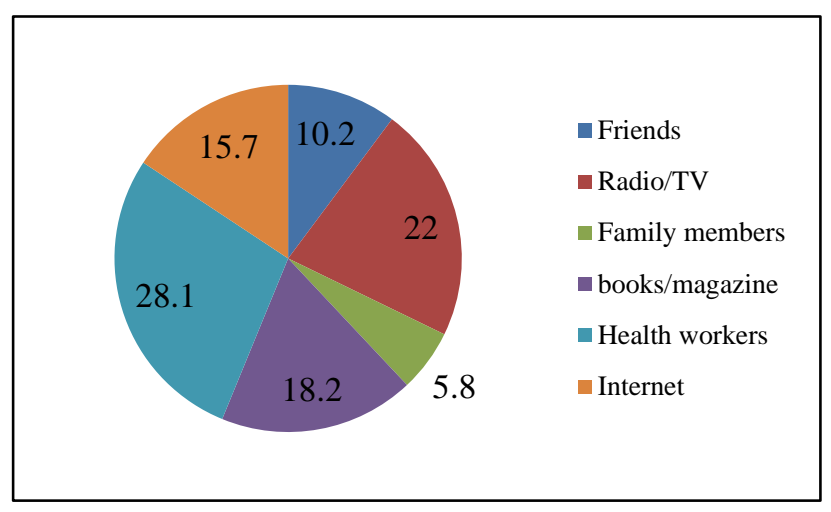

Figure 1: Sources of information of BSE among the respondents.

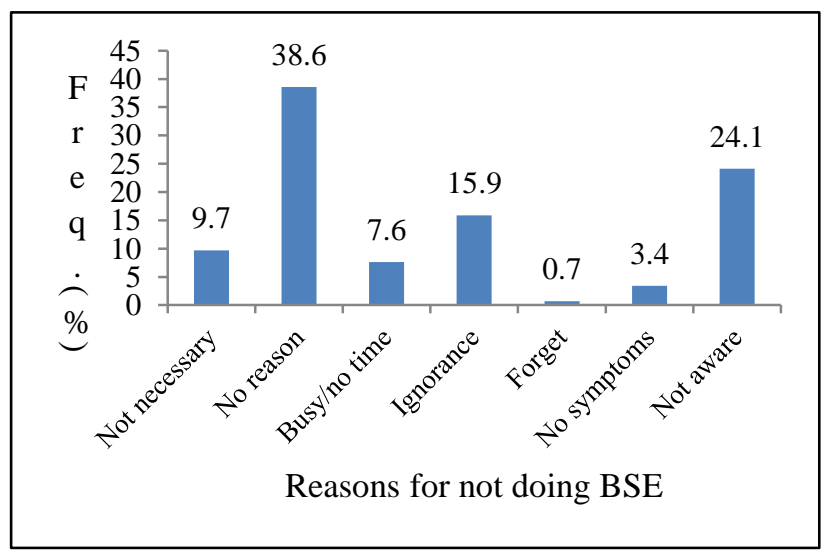

Figure 2: Reasons for not performing BSE among respondents who were not doing BSE.

Table 5: Attitude of the respondents on breast cancer, August 2013.

$\begin{array}{lll}\text { Variable } & \text { Frequency } & \text { Percentage } \\ \begin{array}{l}\text { What would you do if you } \\ \text { notice a lump }\end{array} & \\ \text { Consult a doctor } & 361 & 90.0 \\ \text { Go to chemist } & 11 & 2.7 \\ \text { Go to prayer/spiritual house } & 13 & 3.2 \\ \text { Use traditional herbs } & 4 & 1.0 \\ \text { Wait and see } & 12 & 3.0 \\ \text { How soon will you seek } & & \\ \text { help } & 354 & 88.3 \\ \text { Immediately, within days } & 15 & 3.7 \\ \text { Within a month } & 4 & 1.0 \\ \text { May delay for a few month } & 28 & 7.0 \\ \text { May wait } & & \\ \text { Wants to know more about } & & 79.8 \\ \text { BSE } & 320 & \\ \text { Yes } & \end{array}$


Similarly the awareness on BSE was high among our respondents $(90 \%)$; this may be as a result of their level of education. Health workers were the main sources of information $(28 \%)$, while in similar study done in the northern Nigeria, the media was the main source of information $45 \%$ and Ghana $48 \%$ respectively. ${ }^{13,14}$ However, the level of practice was very low, about $13.7 \%$ and $9.0 \%$ claimed that they practiced BSE weekly and monthly respectively, about $44 \%$ had not done BSE in the last 3 months, showing a wide gap between awareness and practice and this is similar to other studies in this setting. In Zaria $87 \%$ of the respondents were aware of BSE while $19 \%$ practice it monthly. ${ }^{13}$ A study done among female undergraduates in 24 low middle countries which included Nigeria showed that-only $9.1 \%$ of the students practiced BSE monthly Regular monthly BSE is the simplest, economical, and non-invasive way of detecting breast cancer and more than $90 \%$ of breast cancer is still being detected by women themselves. ${ }^{15-17}$ The knowledge of BSE was shown to be very poor among the respondents, this was rather surprising and disappointing because as a tertiary level of education; the students would be more knowledgeable about BSE. It is obvious from this study that even those that performed BSE did not know the right timing and frequency; a similar finding was reported in Ghana. ${ }^{14}$ The poor practice of BSE could be due to the fact that the students were not convinced of the benefits of BSE that was why about $38.6 \%$ could not give any reason and $9 \%$ did not find it necessary, while $16 \%$ were completely ignorant of how it is done.

Table 6: Level of risk of the respondents.

\begin{tabular}{|lll|}
\hline Level of risk & Frequency & Percentage \\
\hline $\begin{array}{l}\text { Menarche below 13 years } \\
\text { Yes }\end{array}$ & 101 & 25.2 \\
\hline $\begin{array}{l}\text { Age at first delivery } \\
30 \text { and above }\end{array}$ & 3 & 0.7 \\
\hline $\begin{array}{l}\text { Previous history of lumps } \\
\text { Yes }\end{array}$ & 29 & 7.2 \\
\hline $\begin{array}{l}\text { Family history of breast } \\
\text { cancer }\end{array}$ & 23 & 5.7 \\
\hline $\begin{array}{l}\text { High risk (family history } \\
\text { of breast cancer with at } \\
\text { least one of the above }\end{array}$ & 14 & \\
\hline
\end{tabular}

Median age of menarche is 13 , IQR $10-16$ years

Concerning risk factors for breast cancer, the result of this study showed that $5.7 \%$ of the respondents had family history of breast cancer, this is lower than $9.0 \%$ reported in United Arab Emirate, family history of breast cancer has been reported to be the strongest predictor of lifetime risk of breast cancer, the median menarche is 13 years which is at the upper normal for breast cancer, early menarche. ${ }^{18,19}$ Early menarche with late menopause is an established risk of breast cancer, thus the younger women are, at menarche, the higher the risk of breast cancer this risk increased by about $5 \%$ for every year younger and with the current global trend of declining age at menarche, theoretically, the incidence of breast cancer may continue to increase..$^{20,21}$

In conclusion, though the awareness on breast cancer and the BSE is high among the study population the level of knowledge of breast cancer and BSE is still very low leading to poor BSE performance, this underscores the need for intensive health education among the students especially since majority of them were interested in knowing more about BSE, specifically we recommend that orientation programme for fresh students should include talks on screening for breast cancer. Media activities should also be intensified to give reliable information about breast cancer and BSE. Proper education of the female students will have a positive impact on the society at large.

\section{Funding: No funding sources}

Conflict of interest: None declared

Ethical approval: The study was approved by the Institutional Ethics Committee

\section{REFERENCES}

1. WHO. Latest world cancer statistics Global cancer burden rises to 14.1 million new cases in 2012: Marked increase in breast cancers must be addressed In: IARC, editor. Lyon, France: International Agency for Research on Cancer. 2013:1-3.

2. WHO. Breast cancer: prevention and control Geneva: World Health Organisation; 2015. http://www.who.int/cancer/detection/breastcancer/e n/index1.html. Accessed 24 May, 2015

3. WCRF. Breast Cancer Statistics. London: World Cancer Research Fund International; 2015. http://www.wcrf.org/int/cancer-facts-figures/dataspecific-cancers/breast-cancer-statistics. Accessed 24 May, 2015.

4. Jedy-Agba E, Curado MP, Ogunbiyi O, Oga E, Fabowale T, Igbinoba F, et al. Cancer incidence in Nigeria: a report from population-based cancer registries. Cancer epidemiology. 2012;36:e271-8.

5. Obaji N, Elom H, Agwu U, Nwigwe C, Ezeonu P, Umeora O. Awareness and Practice of Breast SelfExamination among Market Women in Abakaliki, South East Nigeria. Annals of medical and health sciences research. 2013;3:7-12.

6. Khokhar A. Level of awareness regarding breast cancer and its screening amongst Indian teachers. Asian Pacific journal of cancer prevention. APJCP. 2009;10:247-50.

7. Azage M, Abeje G, Mekonnen A. Assessment of Factors Associated with Breast Self-Examination among Health Extension Workers in West Gojjam Zone, Northwest Ethiopia. International journal of breast cancer. 2013;2013:814395.

8. Kalander A, Salah MA, Sanjor KP, Khalid A, Gebrehiwot GK. Breast Cancer Awareness and 
Practice of Breast Self-Examination among Female Medical Students in Haramaya University, Harar, Ethiopia. International Journal of Interdisciplinary and Multidisciplinary Studies. 2014;2:10.

9. Peacey V, Steptoe A, Davidsdottir S, Baban A, Wardle J. Low levels of breast cancer risk awareness in young women: an international survey. European journal of cancer. 2006;42:2585-9.

10. Azim HA, Patridge AH. Biology of breast cancer in young women. Breast Cancer Research. 2014,16(4):427

11. Adegbenro CA, Ajala AM, Ajayi OO, Ajayi TD. Awareness of Breast cancer and Practice of breast self-examination among Rural Women in I fe North Logal Government Area, Osun State, South West Nigeria. Journal of Community Medicine and Primary Health care. 2014;26(1):76-87.

12. Oluwatosin OA, Oladepo O. Knowledge of breast cancer and its early detection measures among rural women in Akinjola Local governement area, Ibadan, Nigeria. BMC cancer, 2006:6;271

13. Gwarzo UM, Sabitu K, Idris SH. Knowledge and practice of breast-self examination among female undergraduate students of Ahmadu Bello University Zaria, Northwestern Nigeria. Ann Afr Med. 2009;8:55-8.

14. Akuamoah L, Awuah-Peasah DS, Acheampong E, Asamoh F. Knowledge, attitude and practice of selfbreast Examination among female university students at Presbyterian University College, Ghana. American Journal of Research Communication, 2013;1(11):395-404

15. Supa P, Karl P. Knowledge Attitude and Practice of Breast self -examination among Female University students from 24 low, Middle Income and Emerging Economy Countries. Asian Pac. J. Cancer Prev. 2014;15(20):8637-40

16. Breast inplants and cancer risks. www.mdanderson.org/patients-and-cancerinformation. Accessed 20th July 2015.

17. Balogun MO, Owoaje ET. Knowledge and Practice of Breast Self-Examination among Female Traders in Ibadan, Nigeria. Annals of Ibadan postgraduate Medicne. 2005;3(2):52-6.

18. Al-Sharbatti SS, Shaikh RB, Mathew E, Salman AlBarte MA. Breast Self-Examination Practice and Breast Cancer Risk Perception among Female University Students in Ajman. Asian Pac J Cancer Prev. 2013;14(18):4919-23.

19. Breast cancer Risk factors: available at www.emedicine.medscape.com/article/1945957overview. Accessed July 22nd 2015.

20. Collaborative Group on Hormonal Factors in Breast Cancer. Menarche, menopause, and breast cancer risk: individual participant meta-analysis including 118,964 women with breast cancer from 117 epidemiological studies. Lancet oncol. 2012;13(11):1141-51.

21. Tanner JM. Menarcheal age. Science: 1981;214(4521):604-6.

Cite this article as: Motilewa OO, Ekanem US, Ihesie CA. Knowledge of breast cancer and practice of selfbreast examination among female undergraduates in Uyo, Akwa Ibom State, Nigeria. Int J Community Med Public Health 2015;2:361-6. 